\title{
UPAYA MENGEMBANGKAN KEMAMPUAN MOTORIK HA- LUS ANAK MELALUI PEMANFAATAN BAHAN BEKAS DA- LAM PEMBELAJARAN DI KELOMPOK B RA AR-RAFIF KALASAN, SLEMAN, YOGYAKARTA
}

\author{
Afifah Fatihakun Ni'mah Wahidah dan Erni Munastiwi \\ Universitas Islam Negeri Sunan Kalijaga, Yogyakarta \\ Email: afifah.fatiha25@gmail.com
}

\begin{abstract}
The purpose of this research to find the efforts of development children's motor fine skills in group B RA Ar-Rafif, Kalasan, Sleman, Yogyakarta through utilization of used materials. The type of this research is collaborative classroom action research which is uses research model by Kurt Levin. The Method of collect data are observation, interviews, and documentation. The current data analysis are descriptive, qualitative, and quantitative. The Indicator of success minimum is very high category and children's motor fine skills minimum $85 \%$ which develop as expected category (develop as expected and develop very well) from 12 children. This research was conducted in two cycles, each cycle consist of three meetings. The Research process are planning, implementation, observation, and reflection. The results showed that: First, development children's motor fine skills before given action 16,67\% which develop as expected category (develop as expected and develop very well), the ability motor fine skills of childhood less optimal. Second, implementation utilization of used materials in learning in group B RA Ar-Rafif Kalasan can increase children's motor fine skills. Third, development children motor fine skills after given action an increase cycle 1 of $50 \%$ (develop as expected and develop very well) and increase cycle 2 of 91,66\% (develop as expected and develop very well).
\end{abstract}

Keywords: motor fine skills, utilization of used materials, learning 


\section{PENDAHULUAN}

Pendidikan Anak Usia Dini adalah suatu proses pembinaan tumbuh kembang anak usia lahir hingga enam tahun secara menyeluruh, yang mencakup aspek fisik dan non-fisik, dengan memberikan rangsangan bagi perkembangan jasmani, rohani (moral dan spiritual), motorik, akal pikir, emosional, dan sosial yang tepat agar anak dapat tumbuh dah berkembang secara optimal. Pendidikan anak usia dini sebagai sebuah lembaga pendidikan yang berperan penting untuk mengoptimalkan masa emas anak (golden age) dan membentuk pondasi kehidupan lebih lanjut bagi anak. Menurut Teyler yang dikutip Imam Musbikin mengatakan bahwa otak anak ketika lahir berisi sekitar 100 miliar hingga 200 miliar sel saraf dan sel saraf siap berkembang sampai taraf tertinggi dari kapasitas manusia jika mendapat stimulasi yang sesuai dari lingkungannya.

Pertumbuhan dan perkembangan sel syaraf pada anak akan mempengaruhi kinerja otaknya yang akan berfungsi untuk memenuhi kebutuhan anak, misalnya pertumbuhan dan perkembangan kemampuan motorik halus anak. Perkembangan motorik pada anak usia dini akan berkembang secara optimal jika mendapatkan stimulasi yang tepat. Perkembangan motorik halus yang baik dapat dilihat ketika anak sudah bisa melakukan kegiatan seperti apa yang dilakukan teman-teman sebayanya. Ini merupakan satu ciri yang bisa dijadikan usaha bagi orangtua ataupun guru di lembaga PAUD melihat apakah anak-anaknya sudah berkembang belum dalam hal motorik halusnya, karena jika perkembangan motorik halus ini belum berkembangan di usia yang seharusnya berkembang akan sangat mempengaruhi anak itu sendiri. Beberapa kegiatan yang dilakukan untuk mengembangkan motorik halus ini bisa dengan kegiatan mewarnai, menggunting dan menempel.

Masalah yang dihadapi oleh para pendidik saat ini mengenai keterampilan motorik halus ini adalah diantaranya kurang minatnya anak mengikuti kegiatan di atas, yaitu mewarnai, menggunting dan menempel. Sehingga harus adanya suatu pemecahan dari masalah yang dijelaskan atas tersebut, yang harus melibatkan semua elemen dalam sekolah dan orang-orang disekitar anak yang bersangkutan.

Bahan/barang diartikan sebagai benda yang berwujud sedangkan arti kata bekas adalah sisa habis dilalui. Jadi dapat disimpulkan bahwa bahan bekas adalah benda yang sudah pernah dipakai baik sekali maupun lebih dari satu kali. Bahan bekas ini dapat diubah menjadi sebuah media pembelajaran yang menarik buat anak-anak. Disinilah dibutuhkan kreativitas 
guru untuk menciptakannya, hal itu tentunya tidaklah begitu sulit, media yang dapat digunakan untuk membantu siswa dalam memahami materi pelajaran tidaklah harus yang modern, mahal dan buatan pabrik, tetapi juga media sederhana dan murah yang dibuat dari bahan bekas ataupun sisa pakai yang ada di sekitar lingkungan masing-masing.

Deskripsi di atas menjelaskan bahwa sangat diperlukan pembelajaran keterampilan yang dapat meningkatkan kemampuan motorik halus pada anak. Salah satunya keterampilan yang dapat mengembangkan motorik halus adalah dengan melalui kegiatan pemanfaatan bahan bekas dalam pembelajaran.

Berdasarkan permasalahan yang diuraikan di atas, penelitian ini mengambil judul tentang "Upaya Mengembangkan Kemampuan Motorik Halus Anak Melalui Pemanfaatan Bahan Bekas dalam Pembelajaran di Kelompok B RA Ar-Rafif Kalasan Sleman Yogyakarta". Harapannya dengan penelitian ini dapat mengembangkan kemampuan motorik halus anak melalui kegiatan mewarnai, menggunting dan menempel dalam pemanfaatan bahan bekas. Dengan begitu motorik halus anak dapat berkembang secara baik dan berkualitas sekaligus mampu memenuhi perkembangan zaman serta bahan-bahan bekas yang ada disekitar sekolah dapat dimanfaatkan dengan baik sesuai dengan kebutuhan sekolah, yaitu sebagai media pembelajaran yang menarik untuk anak-anak.

\section{Metode Penelitian}

Jenis penelitian dalam penelitian ini adalah Penelitian Tindakan Kelas. Penelitian Tindakan Kelas (PTK) diartikan sebagai penelitian yang dilakukan oleh guru di kelas (sekolah) tempat ia mengajar dengan tekanan pada penyempurnaan atau peningkatan proses dan praktis pembelajaran. Penelitian yang dilaksanakan di RA Ar-Rafif Kalasan ini menggunakan model penelitian yang dikembangkan oleh Kurt Levin. Model yang dikembangkan oleh Kurt Levin pertama dalam kegiatan PTK yang diperkenalkan sejak tahun 1946 dan merupakan acuan pokok dari berbagai model PTK lain. Konsep inti dalam PTK Kurt Levin, bahwa dalam setiap siklus PTK terdiri dari empat langkah, yakni: perencanaan (planning), aksi atau tindakan (action), observasi (observation), dan refleksi (reflecting).

Adapun penelitian ini terdiri dari dua siklus. Pelaksanaan siklus kedua sama dengan siklus pertama menggunakan instrumen yang sama, akan tetapi yang membedakan adalah media bahan bekas yang digunakan berbeda dalam kegiatan mewarnai, 
menggunting dan menempel sesuai indikator keberhasilan yang ditentukan.

Teknis dari penelitian ini yaitu peneliti berkolaborasi dalam kegiatan pembelajaran dimana yang bertindak sebagai pelaku tindakan adalah guru dan peneliti, disamping peneliti sebaigai pelaku tindakan peneliti sekaligus bekerjasama dengan guru mengidentifikasi permasalahan, menyusun rencana tindakan, mengamati, pelaksanaan dan merefleksikan kegiatan $\mathrm{m}$ serta terlibat dalam beberapa kegiatan pembelajaran.

\section{Hasil Penelitian dan Pembahasan}

Sujiono menyatakan bahwa "Gerakan motorik halus merupakan gerakan yang hanya melibatkan bagian-bagian tubuh tertentu saja dan dilakukan oleh otot-otot kecil, seperti keterampilan menggunakan jari jemari tangan dan gerakan pergelangan tangan yang tepat." Oleh karena itu, gerakan ini tidak perlu membutuhkan tenaga, namun gerakan ini membutuhkan kecepatan serta koordinasi mata dan tangan yang cermat. Aktivitas motorik halus (fine motor activity) ialah sebagai keterampilan yang memerlukan kemampuan untuk mengkoordinasikan atau mengatur otototot kecil/halus. Misalnya, berkaitan dengan gerakan mata dan tangan yang efisien, tepat, dan adaptif. Perkembangan kontrol motorik halus atau keterampilan koordinasi mata dan tangan mewakili bagian yang penting dalam perkembangan motorik. Contoh aktivitas motorik halus misalnya kemampuan memindahkan benda dari tangan, mencoret-coret, menyusun balok, menggunting, menulis, dan sebagainya.

Sumantri menyatakan bahwa "Sehubungan dengan aspek kemampuan fisik motorik khususnya motorik halus anak, tujuannya adalah agar anak mampu memfungsikan otot-otot kecil seperti kelenturan gerakan jari tangan, mampu mengkoordinasikan kecepatan mata dan tangan yang membutuhkan kecermatan".

Hurlock berpendapat "Bahwa dalam penguasaan motorik halus penting bagi anak, karena seiring makin banyak keterampilan motorik yang dimiliki semakin baik pula penyesuaian sosial yang dapat dilakukan anak serta semakin baik prestasi di sekolah". Optimalisasi perkembangan motorik juga berpengaruh positif terhadap pertumbuhan rasa harga diri (self esteem) dan bahkan perkembangan kognisi. Beberapa kemampuan motorik halus yang penting bagi anak untuk dikembangkan adalah mampu melengkungkan telapak tangan membentuk cekungan, menggunakan ibu jari dan jari telunjuk untuk memegang suatu benda, sambil menggunakan jari manis untuk kestabilan tangan 
mereka, dan membuat bentuk lengkung dengan ibu jari serta jari telunjuk.

Kemampuan anak memainkan jari-jemarinya ini merupakan fondasi oral motorik yang bermanfaat bagi perkembangan wicaranya. Keterkaitan perkembangan ini masih terus bergullir hingga perkembangan wicara menjadi dasar untuk perkembangan kognitif (kecerdasan) anak. Jika perkembangan motorik halus jelek, anak akan mengalami kesulitan untuk mengendalikan tangannya, hal inilah yang menyebabkan ada anak yang kalau memegang sesuatu mudah terjatuh. Hal ini karena tangannya kaku dan tidak luwes.

Perkembangan motorik berarti perkembangan pengendalian gerakan jasmaniah melalui kegiatan pusat syaraf, urat syaraf, dan otot yang terkoordinasi. Pengendalian tersebut berasal dari perkembanagn refleksi dan kegiatan massa yang ada pada waktu lahir. Sebelum perkembangan tersebut terjadi, anak akan tetap tidak berdaya.

Kemampuan mengendalikan tubuh, kalau tidak lebih baik minimal sama baiknya dengan dengan kemampuan teman sebayanya. Sangat penting bagi anak karena beberapa alasan. Perkembangan motorik turut menyumbang bagi penyesuaian sosial dan pribadi anak. Sumbangan perkembangan motorik tersebut yaitu:

a. Kesehatan yang baik: kesehatan yang baik sebagian bergantung pada latihan penting bagi perkembangan dan kebahagian anak. Apabila koordinasi motorik masih buruk sehibngga prestasi anak berada di bawah standart kelompok sebaya, maka anak hanya memperoleh kepuasan sedikit demi kegiatan fisik dan kurang termotivasi dalam mengambil bagian.

b. Kemandirian: semakin banyak anak melakukan sendiri, semakin besar kebahagian dan rasa percaya atas dirinya. Kebergantungan menimbulkan kekecewaan dan ketidakmampuan diri.

c. Hiburan: pengendalian motorik memungkinkan anak berkecimpung dalam kegiatan yang akan menimbulkan kesenangan baginya meskipun tidak ada teman sebaya.

d. Sosialisasi: perkembangan motorik yang baik turut menyumbang bagi penerimaan anak dan menyediakan kesempatan untuk mempelajari keterampilan sosial. Keunggulan keterampilan motorik memungkinkan anak memainkan peran kepemimpinan. 
e. Konsep diri: pengendalian motorik menimbulkan rasa aman secara fisik, yang akan melahirkan perasaan amak secara psikologis yang akan menimbulkan rasa percaya diri yang umumnya akan mempengaruhi perilaku.

Bahan bekas merupakan sampah rumah tangga yang ada didapur atau ditong sampah yang terbuang maupun di halaman sekitar rumah seperti botol aqua, daun-daun yang berguguran, kardus-kardus susu dan koran dan lain sebagainya. Bahan bekas dapat ditemukan sekitar lingkungan rumah atau sekolah yang dapat dimanfaatkan menjadi berbagai alat permainan bagi anak. Kreativitas guru dalam menggunakan bahan bekas menjadi media pembelajaran dapat membantu proses pembelajaran. Contohnya botol bekas minuman, kertas bekas (majalah, koran, kantong beras, dII), kardus/karton, bahan/kain, plastik dan kaleng, tali, botol dan karet, tepung, sayuran, kulit buah, dan daundaunan. Botol aqua bekas ini dapat diolah menjadi sutu karya yang kreatif dalam mengkreasikan karya seni seperti membuat kotak pensil, pas bunga, hiasan dinding dan lain-lain.

Media bahan bekas sangat berpengaruh terhadap kesenangan anak untuk bermain, maka penampilannya harus menarik. Penggunaan media bahan bekas pada anak dalam penelitian ini adalah untuk mengembangkan kreativitas anak. Anak dapat membuat mainan dari bahan bekas untuk berkreasi. Media dalam pembelajaran anak usia dini tidak terbatas pada media atau alat peraga yang tersedia didalam kelas, melainkan segala bahan yang ada disekitar dapat digunakan sebagai media pembelajaran. Hal ini justru akan membantu mengeksplorasi berbagai aspek perkembangan anak usia dini. Dalam penggunaanya, media pembelajaran tidak digunakan begitu saja oleh guru karena menurut Gagne tidak ada satu mediapun yang mungkin paling cocok untuk mencapai semua tujuan. Media pembelajaran yang kita gunakan untuk satu tipe pokok bahasan akan berbeda dengan isi pokok bahasan yang lain. Untuk itu beberapa prinsip dalam memilih media akan sangat membantu guru memilih dan menggunakan media yang tepat sesuai dengan tujuan pembelajaran.

Pembelajaran tidak akan optimal apabila suatu sekolah tidak menyediakan sarana yang memadai. Hal ini didasarkan pada prinsip belajar anak yaitu anak belajar menggunakan panca inderanya. Untuk belajar bermakna anak perlu alat peraga edukatif maupun alat permainan edukatif yang membantu memaksimalkan eksplorasi, penemuan, penciptaan, perkembangan daya pikir sehingga apabila tidak tersedia alat bantu tersebut, guru yang harus mengupayakan dengan cara memanfaatkan lingkungan termasuk bahan sisa/sampah sebagai alat permainan 
edukatif. Permaianan adalah sesuatu yang digunakan untuk bermain. Menurut Asmawati melalui pemanfatan bahan sisa atau daur ulang ini guru diharapkan mampu:

a. Menciptakan permainan baru dengan memanfaatkan bahan sisa dan bahan alam sebagai media bermain bagi anak usia dini.

b. Mengoptimalkan penggunaan bahan daur ulang sebagai sarana bermain atau sumber belajar bagi anak agar lingkungan belajar lebih kaya.

c. Mengetahui aneka ragam bahan sisa yang dapat dijadikan sebagai alat bermain atau sumber belajar.

Menurut Nurani, bahan bekas yang digunakan ini berfungsi sebagai perantara penyaluran informasi dan pengetahuan. Proses daur ulang terdiri atas kegiatan pemilahan, pengumpulan, pemrosesan, pendistribusian, pembuatan produk atau materi bekas pakai. Dalam proses daur ulang sebagai pembelajaran pada anak-anak dapat dimulai dengan pemilahan sampah yang dapat didaur ulang yaitu sampah padat yang tidak berbahaya bagi keselamatan atau kesehatan anak. Setelah itu sampah tersebut dikumpulkan dan dikelompokkan kemudian sampah yang siap didaur ulang dibersihkan terlebih dahulu. Penggunaan alat-alat lain seperti lem, gunting, isolasi, stapler, dan pembolong kertas dapat membantu proses mendaur ulang sampah.

Hasil pembuatan alat permainan berbahan bekas memiliki manfaat, diantaranya:

a. Dapat merangsang daya pikir siswa dari segi kognitif.

b. Dapat melatih kreativitas siswa dari aspek afektif dan psikomotorik karena melatih kesabaran harus telaten.

c. Memberikan edukasi kepada siswa bahwa bahan bekas yang biasa siswa pakai agar tidak dibuang sembarangan karena selain membuat kotor lingkungan ternyata bisa dimanfaatkan lagi menjadi barang yang bernilai tambah.

d. Salah satu alat peraga pemebelajaran yang efektif.

Kegiatan ini anak akan belajar menghasilkan sebuah produk baru yang bermanfaat dari bahan bekas atau sampah. Dari uraian tentang bahan dan proses daur ulang alat permainan edukatif di atas, guru dalam merencanakan dan menerapkannya perlu mempertimbangkan kriteria keamanan bahan yang harus dipertimbangkan. Bontolalu dalam Asmawati menjelaskan pertimbangan keamanan terhadap bahan yang digunakan sebagai alat permainan: 
a. Kayu tidak berserat karena serat kayu dapat menusuk.

b. Bulu bambu yang gatal, bambu yang telah dipotong disisik, dicuci, diampelas agar licin dan halus serta bebas bulu bambu.

c. Sudut tumpul, semua alat permainan diharapkan memiliki sudut yang tumpul.

d. Cat tidak mengandung racun (nontoxid) yaitu menggunakan cat poster, cat minyak.

e. Menjaga kebersihan dengan cara mencuci alat permainan seminggu sekali.

f. Paku yang menonjol harus ditutup dengan lem kayu dan diisolasi tebal.

g. Pembuatan dengan ukuran yang presisi atau ketepatan yaitu ukuran yang akurat diperlukan agar anak mampu mengambil kesimpulan waktu bermain dengan balok.

Penelitian tindakan kelas dilakukan untuk melakukan perbaikan pada pembelajaran yang sudah dirancang sebaik mungkin, perbaikan pada penelitian ini dilakukan dengan menggunakan bahan ajar yaitu bahan bekas. Berikut hasil pembahasan dari penelitian setiap siklus.

\section{Pra Siklus}

Berdasarkan berdasarkan hasil observasi tentang perkembangan motorik halus anak dapat dikatakan belum berkembang. Hal ini ditunjukkan pada data awal hasil observasi tentang perkembangan motorik halus terdapat 5 anak yang mencapai kategori belum berkembang dengan persentase $41,66 \%$, kategori mulai berkembang terdapat 5 anak juga dan kategori berkembang sesuai harapan terdapat 2 anak dengan persentase $16,67 \%$ serta kategori berkembang sangat baik belum ada. Berdasarkan hasil penelitian masih banyak anak yang kurang antusias, mudah menyerah dan menunjukkan suasana kurang senag selama kegiatan. Dengan itulah peneliti menggunakan bahan ajar berupa bahan bekas untuk meningkatkan motorik halus anak dan meningkatkan keantusiasan anak dalam mengikuti pembelajaran.

\section{Siklus I}

a. Perkembangan motorik halus

Perkembangan motorik halus anak pada siklus I menunjukkan peningkatan yang cukup optimal. Dari sebelum tindakan kemampuan anak minimal mencapai pada kategori berkembang 
sesuai harapan sebesar 16,67\% (kategori berkembang sangat baik dan berkembang susai harapan) meningkat menjadi $25 \%$ (kategori berkembang sangat baik dan berkembang susai harapan). Pada siklus I anak cukup antusias mengikuti kegiatan pemanfaatan bahan bekas dalam pembelajaran. Tetapi masih ada anak yang kurang berkonsntrasi dalam mengikuti kegiatan, kekuatan tangan anak belum cukup kuat, koordinasi mata dan tangan anak juga belum maksimal. Beberapa anak masih meminta bantuan guru dalam ke kegiatan pemanfaatan bahan bekas dalam pembelajaran. Namun anak-anak tertarik pada media yang digunakan yaitu bahan bekas untuk kegiatan pemanfaatan bahan bekas dalam pembelajaran. Anak-anak tertarik dengan sesuatu yang baru, ketertarikan anak dapat diketahui saat anak melaksakan kegiatannya.

b. Pelaksanaan kegiatan pemanfaatan bahan bekas dalam pembelajaran

1) Guru memberikan aturan main dalam setiap kegiatan.

2) Guru selalu memberikan aturan main setiap sebelum kegiatan dimulai, agar anak-anak melaksanakan kegiatan dengan tertib, hasil karya hasilnya baik dan selesai tepat waktu.

3) Guru memperkenalkan media yang akan digunakan dalam kegiatan dan manfaatnya.

4) Sebelum kegiatan dimulai, guru menjelaskan terlebih dahulu media yang akan digunakan dan manfaat media tersebut untuk kehidupan sehari-hari. Karena bahan bekas yang digunakan ini sangat menarik perhatian anak, sehingga anak-anak sangat antusias dalam melakukan kegiatan pemanfaatan bahan bekas dalam pembelajaran.

5) Antusiasme anak dalam melaksanakan kegiatan.

6) Anak-anak sangat senang sekali ketika guru membawa bahan bekas ke kelas setiap kegiatan akan dimulai. Anak-anak langsung bertanya" mau membuat apa bu?" dan "mainannya boleh dibawa pulang kan bu?". Namun guru membuat anak penasaran dahulu agar anak-anak selalu mengikut kegiatan dengan tertib.

7) Menggunakan media yang tidak berbahaya untuk anak.

8) Pada siklus I terdapat media bahan alam yang dipakai untuk k kegiatan pemanfaatan bahan bekas dalam pembelajaran yaitu gelas Aqua bekas, kardus, dan kertan karton. Bahan tersebut tidak berbahaya untuk anak 
tapi untuk gelas Aqua sedikit berahaya untuk anak, kalau tidak hati-hati bisa terkena pinggiran gelas yang sudah digunting. Sehingga pada siklus siklus pertama bahan bekas yang digunakan perlu diganti dengan menggunakan bahan bekas yang lainnya. Namun, media yang digunakan sudah menarik perhatian anak-anak karena mereka menyukai sesuatu hal yang baru. Dan media bahan bekas masih jarang digunakan.

\section{Siklus II}

a. Kemampuan motorik halus anak

Melihat hasil pada siklus I, peneliti pada siklus II ini melakukan perbaikan-perbaikan sehingga kemampuan motorik halus anak mengalami peningkatan yang signifikan. Kemampuan motorik halus anak pada siklus I minimal mencapai pada kategori berkembang sesuai harapan sebesar $50 \%$ meningkat pada siklus II menjadi $91,66 \%$ (kategori berkembang sesuai harapan dan berkembang sangat baik). Hal ini didukung dengan adanya perbaikan-perbaikan tindakan yang dilakukan peneliti, yaitu: mengganti bahan bekas yang digunakan untuk kegiatan pemanfaatan bahan bekas dalam pembelajaran berupa kardus dan sterofom. Karena bahan tersebut tidak bahya untuk anak dan dapat dibentuk dengan mudah.

b. Pelaksanaan kegiatan pemanfaatan bahan bekas dalam pembelajaran.

1) Guru memberikan aturan main dalam setiap kegiatan.

Seperti saat siklus I, pada siklus II guru selalu memberikan aturan main setiap sebelum kegiatan dimulai, agar anak-anak melaksanakan kegiatan dengan tertib, hasil karya hasilnya baik dan selesai tepat waktu.

2) Guru memperkenalkan media yang akan digunakan dalam kegiatan dan manfaatnya.

Seperti pada siklus I, sebelum kegiatan dimulai guru menjelaskan terlebih dahulu media yang akan digunakan dan manfaat media tersebut untuk kehidupan sehari-hari. Karena bahan bekas yang digunakan ini sangat menarik perhatian anak, sehingga anak-anak sangat antusias dalam melakukan kegiatan pemanfaatan bahan bekas dalam pembelajaran.

3) Antusiasme anak dalam melaksanakan kegiatan.

Pada siklus II, anak-anak semakin antusias dalam pembelajaran. Buktinya anak-anak selalu bersemangat jika kegiatan pemanfaatan bahan bekas dalam pembelajaran ini diberikan oleh guru. 
4) Menggunakan media yang tidak berbahaya untuk anak.

Pada siklus II, media yang digunakan dalam kegiatan pemanfaatan bahan bekas dalam pembelajaran lebih aman dan mudah untuk membentuknya, sehingga anak tidak takut lagi untuk menggunakannya.

Dalam kategori berkembang sesuai harapan sebelum tindakan terdapat 2 anak dengan persentase $16,67 \%$, pada Siklus I mengalami peningkatan terdapat 6 anak dengan persentase $50 \%$ dan untuk Siklus II terdapat 4 anak dengan persentase 33,33\% dari jumlah anak. Untuk kategori mulai berkembang pada sebelum tindakan terdapat 5 anak dengan persentase $41,67 \%$, pada Siklus I terdapat 3 anak dengan persentase $25 \%$ dari jumlah anak. Untuk kategori belum berkembang sebelum tindakan terdapat 5 anak dengan persentase $41,67 \%$, pada Siklus I terdapat 3 anak dengan perentase $25 \%$ dan siklus II tidak terlihat kembali anak yang masuk dalam kategori belum berkembang.

\section{Simpulan}

Berdasarkan hasil penelitian yang telah dilakukan di RA Ar-Rafif Kalasan Sleman Yogyakarta, dengan kegiatan pemanfaatan bahan bekas dalam pembelajaran maka dapat ditarik kesimpulan bahwa:

1. Sebelum dilakukan tindakan menunjukkan kemampuan motorik halus anak sebesar 16,67\% dengan kategori berkembang sesuai harapan (kategori berkembang sesuai harapan dan berkembang sangat baik) dari jumlah anak. Untuk kategori belum berkembang terdapat 5 anak dengan persentase $41,66 \%$, kategori mulai berkembang terdapat 5 anak dengan persentase $41,66 \%$, kategori berkembang sesuai harapan terdapat 2 anak dengan persentase 16,67\%. Hal itu disebabkan oleh media yang kurang menarik perhatian untuk anak dan kurangnya variasi dari guru, sehingga anak mudah bosan dengan kegiatannya dan kemampuan motorik halus anak menjadi belum berkembang secara optimal.

2. Pelaksanaan kegiatan pemanfaatan bahan bekas dalam pembelajaran di kelompok B RA Ar-Rafif Kalasan Sleman Yogyakarta terbukti dapat meningkat kemampuan motorik halus anak. Pelaksanaan kegiatan pemanfaatan bahan bekas dalam pembelajaran pada siklus I mencapai pada kategori rendah kemudian pada siklus II pelaksanaan kegiatan pemanfaatan bahan bekas dalam pembelajaran mengalami peningkatan pada kategori sangat tinggi. Peningkatan tersebut dapat dilihat pada masing-masing aspek 
kegiatan pemanfaatan bahan bekas dalam pembelajaran. Peningkatan terjadi karena adanya kemauan anak untuk mengikuti kegiatan pembelajaran dan anak terlihat antuas selama proses belajar. Hal tersebut dapat dilihat selama kegaiatan berlangsung anak mampu berkonsentrasi, kekuatan tangan yang sudah baik serta koordinasi mata dan tangan yang sudah sangat baik. Penggunaan media dari bahan bekas dapat menstimulasi anak menjadi antusias, senang, dan tidak mudah menyerah.

3. Penigkatan perkembangan motorik halus anak setelah diberikan tindakan berikut dapat dibuktikan oleh adanya peningkatan pada siklus I anak sebesar $50 \%$ dengan kategori Belum Berkembang terdapat 3 anak dengan persentase $25 \%$, kategori Mulai Berkembang terdapat anak 3 dengan persentase $25 \%$, kategori Berkembang Sesuai Harapan terdapat 6 anak dengan persentase 25\%, kategori berkembang sangat baik belum ada. Meningkat pada siklus II menjadi 91,66\% kategori Berkembang Sesuai Harapan terdapat 7 anak dengan prosesntase 33,33\%, kategori berkembang sangat baik terdapat 4 anak dengan persentase $33,33 \%$.

\section{DAFTAR PUSTAKA}

Arsyad, Azhar. 2011. Media Pembelajaran. Jakarta: PT Raja Grafindo Persada.

Departemen Agama Rl. 2010. Al Qur'an dn terjemahannya. Bandung: CV Penerbit Diponegoro.

Dimyati, Johni. 2013. Metodologi Penelitian Pendidikan dan Aplikasinya pada Pendidikan Anak Usia Dini (PAUD). Jakarta: Kencana

Eni Kusmiyati Elfita Kadarmayanti. 2014. Upaya Meningkatan Kemampuan Motorik Halus Keterampilan Menggunting dengan Metode Demonstrasi pada Kelompok A di BA Aisyiyah Salam 1 Salam Tahun Pelajaran 2013/2014. Yogyakarta: Fakultas IImu Tarbiyah dan Keguruan Jurusan Pendidikan Islam Anak Usia Dini Universitas Islam Negeri Sunan Kalijaga Tahun.

Fadillah, Muhammad. 2012. Desain Pembelajaran PAUD. Yogyakarta: Ar-Ruzz Media.

Hamdani. 2010. Strategi Belajar Mengajar. Bandung: CV. Pustaka Setia. 
Hari Soetjiningsih, Christiana. 2012. Perkembangan Anak Sejak Pembuahan Sampai dengan Kanak-kanak Akhir. Jakarta: PRENADA.

Hasan, Maimunah. 2010. PAUD (Pendidikan Anak Usia Dini). Yogyakarta: Diva Press.

A. Hurlock, Elizabeth. 2007. Perkembangan Anak. Jakarta: Erlangga.

Irma Oktaviani Ana Sari. 2014. Meningkatkan Perkembangan Motorik Halus anak melalui Kegiatan 3M (Mewarnai, Menggunting, Menempel) dengan Metode Demonstrasi di Kelompok A1 TK Pertiwi 39 Trimulyo, Jetis, Bantul. Yogyakarta: Fakultas IImu Tarbiyah dan Keguruan Jurusan Pendidikan Islam Anak Usia Dini Universitas Islam Negeri Sunan Kalijaga Tahun.

Jatmika, Yusep Nur. 2012. Ragam Aktivitas Harian untuk Playgroup. Yogyakarta: Diva Press

Kumala Sari, Effi. Peningkatan Perkembangan Motorik Halus Anak melalui Kegiatan Kolase dari Bahan Bekas di Taman Kanak-Kanak Aisyiyah Simpang IV Agam, Jurnal Pesona PAUD Vol.1 No. 1, http://journal.unp.ac.id/index.php/paud/article/view/1615, diakses pada Rabu 19 Desember 2018 pukul 19.00.

Lita. 2017.Pendidikan Seni Rupa dan Implikasinya Terhadap Imajinasi Kreatif dan Soisal Emosianal Anak Usia Dini di TK Mekarraharja Talaga Majalengka Jawa Barat. Yogyakarta: Fakultas IImu Tarbiyah dan Keguruan Jurusan Pendidikan Islam Anak Usia Dini Universitas Islam Negeri Sunan Kalijaga.

M. Purwanto, Ngalim. 2006. Prinsip-Prinsip dan Teknik Evaluasi Pengajaran. Bandung: Remaja Rosdakarya

Mardapi, Djemari. 2008. Teknik Penyusunan Instrumen Tes dan Non Tes. Yogyakarta: Mitra Cendekia.

Mila Ummu Walidatul Hamidah dan Siti Rahmany Aprilina. Peningkatan Motorik Halus Anak Melalui Pembuatan Media Daur Ulang di Lingkungan Sekolah. Jurnal PG PAUD Trunojoyo: Jurnal Pendidikan dan Pengajaran Anak Usia Dini. (Online), Vol 3, No 1 (2016) (http://journal.trunojoyo.ac.id/pgpaudtrunojoyo/article/view /3485/2571), diakses pada Rabu, 19 Desember 2018 pukul. 20:00. 
Mudlofir, Ali dan Fatimatur Rusydiyah, Evi. 2017. Desain Pembelajaran Inovatif. Jakarta: Rajawali Pers.

Mursid. 2015. Belajar dan Pembelajaran PAUD. Bandung: PT Remaja. Rosdakarya.

Musbikin, Imam. 2010. Buku Pintar PAUD dalam Perspektif Islam. Yogyakarta: Laksana.

Prastowo, Andi. 2011. Pengembangan Sumber Belajar. Yogyakarta: Fakultas Tarbiyah dan Keguruan UIN Sunan Kalijaga Yogyakarta.

Rahyubi, Heri. 2012. Teori-toeri Pembelajaran Motorik. Bandung: Nusa Media.

Rohani. Meningkatkan Kreativitas Anak Usia Dini Melalui Media Bahan Bekas. (Online).(http://jurnaltarbiyah.uinsu.ac.id/index.php/raudha h/article/view/181/164), Diakses pada Sabtu, 12 Januari 2019 pukul 11:20.

S. Sarina, M. Ali, H. Halida. Meningkatkan Kemampuan Motorik Halus Melalui Kegiatan Menggunting Dan Menempel Pada Anak Kelompok B1 Di Tk Aba Karangbendo Banguntapan Bantul, Jurnal Pendidikan dan Pembelajaran. (Online), Vol 6, No 11 (2017) (https://core.ac.uk/download/pdf/33512508.pdf) diakses pada Rabu, 20 Desember 2018.

Sangadji, Etta Mamang dan Sopiah. 2010. Metodologi Penelitian Pendeketan Praktis dalam Penelitian. Yogyakarta: Andi.

Sanjaya, Wina. 2009. Penelitian Tindakan Kelas. Jakarta: Kencana Prenada Media Group.

Siti Aliyah Mufid. 2017. Pemanfaatan Sampah Sebagai Alat Peraga Edukatif Bagi Siswa-Siswi Paud JDC, (Online), (https://ejournal.unisnu.ac.id/JDC/article/view/439/775). Vol. 1 No. 1 Januari. Diakses pada sabtu 12 Januari 2019 pukul 11.40.

Sujiono, Yuliani Nurani dan Sujiono, Bambang. 2010. Bermain Kreatif Berbasis Kecerdasan Jamak. Jakarta: PT Indeks.

Sujiono. 2009. Metode Pengembangan Fisik. Jakarta: Rineka Cipta.

Sumantri. 2005. Model Pengembangan keterampilan Motorik Anak Usia Dini. Jakarta: Departemen Pendidikan Nasional. 
Tamo Ina Talu, Adriani. Pemanfaatan Alat Permainan Edukatif Daur Ulang Dalam Pembelajaran Sains Anak Usia 5-6 Tahun, Jurnal Pendidikan dan Kebudayaan Missio, Volume 9, Nomor 2, Juni 2017, hlm. 160-170, (Online), http://ejournal.stkipsantupaulus.ac.id/index.php/jpkm/articl e/view/125/101, Diakses pada hari Sabtu, 12 Januari 2019 pukul 11:25.

Watini. 2014. Peningkatan Kemampuan Motorik Halus Anak dengan Metode Demonstrasi dalam Pemanfaatan Bahan Bekas pada Kelompok B di Raudhatul Athfal Jamus Ngluwar Magelang Tahun Ajaran 2013/2014. Yogyakarta: Fakultas IImu Tarbiyah dan Keguruan Jurusan Pendidikan Guru Madrasah Ibtidaiyah Universitas Islam Negeri Sunan Kalijaga.

Zainal Aqib, dkk. 2017. (PTK) Penelitian Tindakan Kelas. Yogyakarta: Ar-Ruzz Media. 

AL HIKMAH: INDONESIAN JOURNAL OF EARLY CHILDHOOD ISLAMIC EDUCATION

ISSN (P): 2550-2200, ISSN (E): 2550-1100, VOL. 3 (1), 2019, PP. $1-15$ 